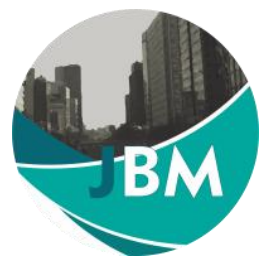

\title{
Brand Promotion: The Effects of Celebrity Endorsement and Brand Image on Consumer Buying Decision
}

\author{
Submitted Date: \\ 3 Februari 2021 \\ Accepted Date: \\ 26 Februari 2021
}

\author{
Adinda Nur Annissa \\ Universitas Kristen Satya Wacana \\ adindaannissa24@gmail.com \\ Eristia Lidia Paramita \\ Universitas Kristen Satya Wacana \\ eristia.paramita@uksw.edu
}

\section{Suggested Citation:}

Chhajer, D., Naidu, K., \& Shah, N. V. (2015). Study of Impact of Celebrity Endorsement on Consumer Buying Behaviour. International Conference on Technology and Business Management, 417-423.

\section{Abstract:}

In the recent years, the influence of celebrity in promoting a brand is promising. Without a doubt, celebrity endorsement will boost business brand awareness with an endorsement. This research objective is to analyse the effect of celebrity endorsement and brand image toward the customer buying decision. The purpose of this study is to provide guidance for both the brand and celebrities regarding to endorsing. The population was the consumer of Maybelline in Indonesia. Purposive sampling was used in this research with 216 respondent. Multiple regression analysis method was used in this research. This research implies that celebrity endorsement and brand image affected the customer buying decision and the result is that Celebrity Endorsement and Brand Image of Maybelline have a positive significant influence on the buying decision.

Keywords: Brand Image, Buying Decision, Celebrity Endorsement, Cosmetics

Abstrak :

Di dalam beberapa tahun terakhir, pengaruh selebriti dalam mempromosikan suatu merek cukup menjanjikan. Tanpa ragu, dukungan selebriti akan meningkatkan kesadaran merek bisnis dengan dukungan. Penelitian ini bertujuan untuk menganalisis pengaruh celebrity endorsement dan brand image terhadap keputusan pembelian konsumen. Tujuan dari penelitian ini adalah untuk memberikan panduan bagi brand dan selebriti terkait dengan endorsing. Populasi adalah konsumen Maybelline di Indonesia. Teknik purposive sampling digunakan dalam penelitian ini dan mendapatkan 216 responden. Metode analisis yang digunakan di dalam penelitian ini adalah regresi linear berganda. Penelitian ini mengimplikasikan bahwa celebrity endorsement dan brand image berpengaruh terhadap keputusan pembelian konsumen dan hasilnya adalah celebrity endorsement dan brand image Maybelline berpengaruh positif signifikan terhadap keputusan pembelian.

Kata Kunci: Brand Image, Celebrity Endorsement, Keputusan Pembelian, Kosmetik

JEL Classification: M31, M37 


\section{Research Background}

Promotion is a way of marketers to inform, remind, or persuade consumers to influence their opinion or attain a response. Firms do the promotional strategies because company goals are widely varied so they use some forms of promotion. Promotion aims to create awareness, provide information, educate the customers, and get the consumers to try certain products (Gitman et al., 2018). One of the promotion activities is advertising. The usage of social media leads firms to start using social media as an advertising media. A phenomenon in a world of advertising or marketing communication is the use of celebrity endorsement. One of the most prevalent types of marketing is the use of celebrity endorsement (Halonen-Knight \& Hurmerinta, 2010). When celebrities are hired to endorse brands, they can gain more attention to the advertisement. Recently, companies are spending much money in endorsing celebrities and, at the same time, are repositioning their product in the consumer's mind by creating a good and positive awareness of the product and brand (Ifeanyichukwu, 2016).

Companies now believe that the power of brand lies in the consumer's mind. In Indonesia itself, celebrity endorsement is used to gain attention from the consumers. Many brands are using celebrity for their way of marketing and use social media as their platform of digital marketing. Due to the increasing social media popularity, such as Instagram and YouTube as a media sharing networks in a social media (Storm, 2020), celebrities with numerous followers have recently generated advertising effect (Park \& Lin, 2020). Celebrity seems to be gaining influence of society and popular culture as they attain a power through the social media presence. It is understood that celebrity endorser can create an intense impact or influence on brands and even more with social media (Schimmelpfennig \& Hunt, 2020). The other study stated that the effect of celebrity endorsement can't be overemphasized as an evidence from the empirical study that the use of celebrity influences young adult in buying decision (Ifeanyichukwu, 2016). Nevertheless, based on the impacts stated above, it is expected by the companies that celebrities can bring over the consumer's buying decision.

Today, people are more conscious about the brand compared to the past. One of the factors that can influence the buying decision is brand image. In the perspective of brand communication, brand image is an important element in brand development process. It is related on how consumer communication interprets the brand messages and actualizes it in consumer's life. Thus, it becomes the part of how they construct their self-concept and also for the purchasing product purpose (Wijaya, 2013). Brand image is the beliefs and perception of the consumers about a specific product (Lau \& Phau, 2007). Brand Image develops over time and is based on customers' experience or interaction with the brand. Moreover, the formation of a consistent brand image is a duty for the business because it can make a better relationship towards the customers (Pahwa, 2020). Companies use strategies to build brand image because it becomes an objective and mental feedback of the customers when they are buying a product. Thus, positive brand image exceeds the customer expectations and enhances the brand value of an organization (Juneja, 2015).

The previous studies conducted by Oscar \& Keni (2019) and Foster (2017) linked the influence of brand image to buying decision which both produce positive and significant influences. In line with those previous studies, the study conducted by Oladepo \& Abimbola (2015) stated that brand image has a positive and significant effect on buying decision, it happens because the brand will simplify the decision making when consumers are faced with uncertain conditions so that products with the most powerful brand in the minds of consumers will be chosen. Moreover, other studies that tried to link the effect of celebrity endorsement on buying decision were conducted by Ifeanyichukwu (2016) and Wijayaningrum et al., (2018) which both produced positive and significant relationships.

In contrast, Sengkey \& Wenas (2015) and Hanzaee \& Farsani (2011) found that there is no significant relationship between brand image and buying decision. Moreover, the study conducted by Suwitho et al., (2018) and Chhajer et al., (2015) revealed that celebrity endorsement has no effect on purchasing decisions. This situation arises because consumers judge a celebrity with popularity and physical appearance only to draw attention and advertising is not affecting a purchase (Jamil \& Hassan, 2014). Therefore, the researcher has not found a consistency in the results of those studies. Thus, this study will be conducted to find the positive significant effect of brand image and celebrity endorsement on the consumer's buying decision and support the study conducted by (Oladepo \& Abimbola, 2015) and (Ifeanyichukwu, 2016). In other words, this study can be a complement to the previous studies.

This study will use Maybelline, one of the established cosmetics in Indonesia since 1979. Among cosmetics brands, Maybelline now is the master of driving the social media engagement that makes it winning at social media. For instance, Maybelline has collaborated with Gigi Hadid as their celebrity endorser for a few years. Gigi Hadid 


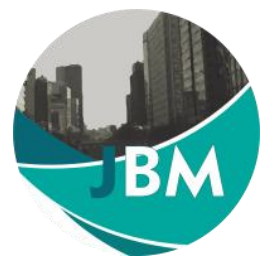

\author{
Jurnal Bisnis dan Manajemen \\ http://jurnal.unmer.ac.id/index.php/jbm/index
}
Volume 8 No 1
2021
HIm. 82 - 90

frequently posts about Maybelline content to her Instagram account with over 36 million followers and mentions Maybelline in comments and tags which is a strategy in helping to push her followers to Maybelline. As a result, after she announced the first online sale on website, it only took 90 minutes for the product to be sold out (Schiffer, 2017). Maybelline Indonesia chose Pevita Pearce as their celebrity endorser with over 15 million followers that she frequently shares about Maybelline and both celebrities are becoming the models on Maybelline products videos and bringing a good image.

This study will try to find whether there are any effects of celebrity endorsement and Brand Image on consumer's buying decision. Thus, the objective of this study is to examine the effect of celebrity endorsement and brand image on consumer's buying decision. This study is going to use celebrity endorsement on YouTube and Instagram as a digital marketing media to promote Maybelline as an international brand for the consumer's interest in Indonesia.

\title{
Literature Review
}

\section{Promotion}

Promotion is a marketing term used to describe all the marketing communication activities, which represents the brand's voice and builds relationship with customers (Kotler \& Keller, 2013). Promotion is considered as a set of practices or marketing techniques and forms of communication aimed to overcome a sales level by capturing attention and attracting potential customers (Alexandrescu \& Milandru, 2019). Promotion needs to be integrated into the business global communication message. It is through the available channels to deliver a clear and consistent message about the company's product, service, and brand (Friesner, 2014).

\section{Celebrity Endorsement}

The use of celebrity as a strategy in marketing communication is a common practice for companies. In consequence of constant innovations during the previous years in marketing, celebrity endorser has become a substantial marketing tool (Kansu \& Mamuti, 2013). Celebrities are people that enjoy public recognition by a share of group of people (Schlecht, 2003). According to one of the latest definition, Celebrity is an individual that has gained attention, riveted interest, and generated profit value that stick from the high level of interest and public attention (Gupta, 2009). The celebrity reputation seems to join together consumers and producers by the meaning of the product that they are associated with (Kansu \& Mamuti, 2013). After all, celebrity endorsement can be defined as popular forms of marketing that are used to promote a range of product and service consumer (Halonen-Knight \& Hurmerinta, 2010).

With the huge amount of social media use, it has changed how companies and customers do things which led the companies starting to change their promotion strategy from using television to social media as their new platform that is designed to attract attention and differentiate their product from the competitors' while influencing buying decision (Ifeanyichukwu, 2016). Celebrity can give a big impact on the product they are endorsing because the message can be delivered to a huge amount of followers constantly. With the message that is delivered to the followers, it is created to attract people's attention to the product and believe that the product is used by those celebrities and influences people to buy it (Jamil \& Hassan, 2014). Based on the previous studies on celebrity endorsement segmentation in distinguishing consumer's buying decision, the author proposes the first research hypothesis as follows:

$\mathrm{H}_{1}$ : Celebrity Endorsement has an effect towards the consumer's buying decision.

\section{Brand Image}

Brand image is the beliefs and perception of the consumers about a specific product (Lau \& Phau, 2007). Moreover, brand image is the way consumers think of brand, and is defined as a perception of customers about the brand. From those definitions, it can be interpreted that brand image as a description obtained by the consumer and formed by the consumer on a certain brand (Foster, 2016). A perception of the consumer about the brand means that consumer will assess whether the brand is considered as more inferior or superior compared to other brands (Lau \& Phau, 2007). 
When a brand is popular, consumers will feel more comfortable to buy the product because it is the thing that they have already known (Aaker \& Biel, 2013). Furthermore, brand image has an important position to influence the consumer's buying decision because one of the decisions in the structure of buying is the decision according to the choice of brand. Brand image has the ability to enhance the consumer buying decision (Silva \& Alwi, 2008). Moreover, when purchasing a product, consumers do not just buy a product as a commodity but also the symbolic value contained in the brand. It is easier for consumers to identify the brand embedded in their minds (Foster, 2016). Brand image facilitates consumers in differentiating the quality of the product with the competitors' products and enhancing the consumer's perception of the quality of the product, which means the perception that has been formed by the brand has the ability to influence the consumer's buying decision (Foster, 2016). Based on the argument that brand image affects the consumer's buying decision, the second research hypothesis is formulated as follows: $\mathrm{H}_{2}$ : Brand Image has an effect towards the consumer's buying decision.

\section{Consumer Buying Decision}

Consumer buying decision is an action towards a variety of alternative actions that are owned, it is a process that starts from problem recognition that can be solved through the product purchase (Brata et al., 2017). When consumer buys a product, they are faced with choices of some existing products before deciding to make a purchase. Purchasing decision is the selection of more than one option to carry out. Consumers make buying decisions based on specific impulses and various motives. The stronger the motives and the consumer's impulse, then the stronger the buying decision of a particular product purchases (Hsin Chang \& Wang, 2011).

Companies have to be able to capture consumer's impulse and motive to make a purchase (Diallo et al., 2013). Companies are required to make a product that can meet the consumer's expectation and motives to buy a product. Moreover, buying decision is the process of integration that combines the knowledge of evaluating behaviour of alternatives and choosing the one of those alternatives. There are five steps of buying decision process, which consist of problem introduction, needs, information search, evaluation of alternatives, buying decision, and after purchase behaviour (Kotler \& Keller, 2013).

\section{Research Method}

The population in this study were the viewers of Maybelline advertisement done by celebrities that are interested in cosmetics. According to Global Business Guide Indonesia (2016), the cosmetics users in Indonesia are mostly women that has reached 126.8 million people and are dominated with people aged 15 to 34 years old (Kunjana, 2018). This study took 216 samples of university students and employees that aged 18 to 34 years old since they afford to make product purchases. This study was using purposive sampling technique. Purposive sampling technique is a technique in which a research selects a sample based on the criteria listed by the researcher. Based on that, the sample requirements and characteristics for this study were: 1 . Women that watch Maybelline advertisement using celebrity, 2. Women that know Maybelline Cosmetics, 3. Women that are interested in Maybelline Cosmetics, 4 . Women that are aged between $18-34$ years old, 5 . Women that make purchase of Maybelline through online or offline stores, 6 . Women that used Maybelline Cosmetics.

The data source was using primary data which obtained from open questionnaires. The empirical indicator that used in this study for Celebrity Endorsement will be Trustworthiness, Expertise, Attractiveness, Respect, and Similatrity (Shimp, (2003) and Karlina, (2018) with adjustment). The Brand Image used Strenght, Uniqueness, and Favorable (Keller, (2008) and Aini, (2015) with adjustment). The Buying Decision used Need Recognition, Information Search, Evaluation Alternatives, Purchase Decision, and Post Purchase Behavior (Foster, 2017). Furthermore, this study conducted a pre-test with around 30 samples that was obtained to check whether the indicators, measurements, and the questionnaire will satisfy the hypothesis. The data were tested to check whether the data is valid and reliable. The classical assumption tests were done in this study, which later followed by multiple regressions test. 


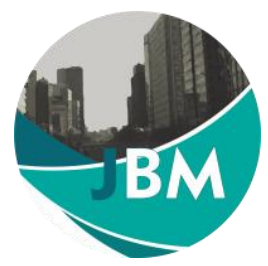

\section{Results}

\section{Pre-Test}

This study conducted the pre-test of validity and reliability test on 30 respondents to ensure that the data collected are reliable and valid. First, the reliability test conducted and will be proven as valid when the result showed that the coefficient of Cronbach's Alpha is greater than 0.70 (Cho \& Kim, 2015). Thus, the data were concluded as reliable since it is greater than 0.70 .

The next test which was conducted is validity test, and the data was proven to be valid when the value of $r, x$, and $y$ are greater than the $r$ table. The $r$ table for the $N=30$ is 0.361 . The result of the validity test stated that the data is proven as valid since the value of $r, x$, and $y>0.361$, thus, from 13 empirical indicators that used in this study, it shows that the data was proven valid and reliable and the study shall move to the next step which is classical assumption test.

\section{Demographics}

Due to a research which stated that the cosmetics user in Indonesia is dominated by women that reach 128.6 million, this study decided to took women as the sample of this study. The respondents of the questionnaires are 216 people varies from age 18 to 34 since the cosmetic users are dominated by that age range and already afford to make purchase. The sample's characteristic was classified by domicile, job and age. The domicile of the samples was dominated from Salatiga by 25.38 . From respondents' job, it was dominated by University Student by 51.85 . From age classification, the respondents were dominated from age $18-22$ by $37.96 \%$.

\section{Hypothesis Testing}

Classical assumption test is the first step that should be completed in the process of hypothesis testing. The first test to be conducted in classical assumption test is normality test. Normality test is conducted to ensure whether the residual of the data is normally distributed or vice versa. The data of this study is considered as normally distributed since the value of residual is greater than the value of significance $(0.200>0.05)$. Due to the data being accepted, this study moved to the next test, which is Multicollinearity test. The purpose of Multicollinearity test is to find is there any correlation in the independent variable. Since the value of tolerance is greater than $0.10(0.505>0.10)$ and and the VIF value is less than $10(1.980<10)$, it is considered that there is no multicolliearity in the. Given that the result of the previous study is accepted, this study proceeded to the next test. Heteroschedasticity test is conducted to see if there is a mismatch variable in a model were analysed using the Glesjer test. This test is comparing the significance of a probability value with a value of 0.05 . The result of the probability value for Celebrity Endorsement is 0.450 and Brand Image is 0.791 . Thus the result of this test is considered as accepted and there is no heteroschedasticity and be able to move to the next test. In conclusion, the data of this study is accepted to move forward to the next test, which is multiple regressions test. The regression model of this study used to show the influence of Celebrity Endorsement (X1), and Brand Image (X2) toward the Buying Decision (Y) of Maybelline as International Brand.

\section{Multiple Regression Test Result}

Table 1. Multiple Regression Test Result

\begin{tabular}{ccccc} 
& \multicolumn{1}{c}{ Model } & \multicolumn{2}{c}{$\begin{array}{c}\text { Spread (basis point) } \\
\text { (Gaussian copula) }\end{array}$} & \multirow{2}{*}{ Sig } \\
\cline { 3 - 4 } & & B & Std. Error & \\
\hline 1 & (Constant) & 9.446 & 3.456 & 0.007 \\
& X1_CelebrityEndorsement & 0.228 & 0.085 & 0.008 \\
& X2_Brandlmage & 1.371 & 0.147 & 0.000 \\
\hline \multicolumn{2}{c|}{ Adjusted R Square $=0.599$} & \multicolumn{3}{c}{$\mathrm{F}=128.145 ;$ Sig $=0.000$} \\
\hline
\end{tabular}

Source: Primary Data (2020) 
From the table above, the multiple regression equation model will be:

$$
Y=9.446+0.228 \times 1+1.371 \times 2+\varepsilon
$$

It means when the variable celebrity endorses increase by 1 unit, the buying decision will increase by $22.8 \%$. Meanwhile, the increase of brand image by 1 unit, it will lead to an increase in buying decision by $137 \%$.

The value of adjusted $\mathrm{R}^{2}$ is 0.599 or $59.9 \%$ of Celebrity Endorsement variable and Brand Image variable have influenced the buying decision. While the other $31.1 \%$ is influenced by other variable that is not in this research. The result of $F$ test that got from ANOVA test is 128.145 which is greater than the $F$ table $(128.145>3.05)$, means the $\mathrm{HO}$ is not accepted and $\mathrm{Ha}$ is accepted. Thus, Celebrity Endorsement and Brand Image have influence toward the Buying Decision. T test is done to see that Celebrity Endorsement and Brand Image have influence on Buying Decision partially.

The statistic result of $\mathrm{T}$ test in this study is that the value of Celebrity Endorsement $(\mathrm{H} 1)$ to Buying Decision is greater than the $T$ table $(2.699>1.65397)$ and the significance value is less than a $(0.008<0.05)$. This study have resulted the beta coefficient value of 0.228 which is positive. Thus, the hypothesis $(\mathrm{H} 1)$ is accepted by stating that Celebrity Endorsement has positive significant influence on the Buying Decision.

The statistic result of T test in this study is that the value of Brand Image $(\mathrm{H} 2)$ to Buying Decision is greater than the $T$ table $(9.315>1.65397)$ and the significance value is less than $a(0.000<0.05)$. This study have resulted the beta coefficient value of 0.228 which is positive. Thus, the hypothesis $(\mathrm{H} 2)$ is accepted by stating that Brand Image has positive significant influence on the Buying Decision.

\section{Discussion}

Based on the result, it is proven that Celebrity Endorsement of Maybelline influence consumer's decision to buy the product. It is because celebrity helping the company in promoting the product and influence their followers to buy the product. This study is in line with the previous studies that done by (Ifeanyichukwu, 2016) and (Wijayaningrum et al., 2018). Majority of women stated that the celebrity endorser is experienced in endorsing with the average score of 4.29 which classified as strongly agree (Boone Jr \& Boone, 2012). Moreover, $51.85 \%$ of university students agreed that Celebrity Endorser is having skill in endorsing (average score 4.30) and 26.38\% people that lives in Salatiga agreed that the celebrity endorser is consistently good in promoting the product (average score 4.03). Thus, they believe that the message that delivered can attract people's attention to the product and believe that the product is used by those celebrities and influences people to buy it (Jamil \& Hassan, 2014).

It is clear that the customers recognize the power and role of a celebrity in promoting the product. The assessment of the customers' show that celebrity endorsement as an advertising strategy if properly combined in terms of blending brand power with celebrity will go a long way in positioning brands in the minds of consumers (Ifeanyichukwu, 2016). Thus, company should consider more in choosing a celebrity as their way of promotion like associate with celebrities with high level of attractiveness, similarity, or expertise since the image of celebrity affects the brand as well.

It is proven that Brand Image of Maybelline influence consumer's decision to buy the product because it helps the company to gain customers' trust and interest in buying the product. Moreover, $37.96 \%$ respondents from age 1822 agreed that the brand of Maybelline has a good quality (with the average score of 4.28), and 31.01 people that work as an employee agreed that the product quality of Maybelline is different from its competitors (average score 3.87). It is because Brand image facilitates consumers in differentiating the quality of the product with the competitors' products and enhancing the consumer's perception of the quality of the product, which means the perception that has been formed by the brand has the ability to influence the consumer's buying decision (Foster, 2017). Thus, the higher the brand image in the minds of customers, the higher the customers' buying decision (Moh, Nur, \& Rommy, 2018). This result is in line with the previous studies that done by Oscar \& Keni (2019), Foster (2017), and Oladepo \& Abimbola (2015).

It is important to attract the consumer's interest from the brand characteristic (Oscar \& Keni, 2019). Thus, company needs to consider about how the brand is easy to be remembered and easy to be pronounced. The unique design of the product is important in attracting the consumer from its appearance and stick on consumers' minds. Moreover, company is advised to enhance a positive brand image in the consumers' eyes, with the company maintaining the quality of products, so that people's buying decisions are getting higher (Moh et al., 2018). 


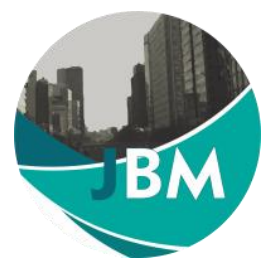

\section{Conclusion}

This study has done analysis on whether the celebrity endorsement and brand image has an influence on the buying decision of the Maybelline cosmetics. The result of this study stated that both variables have a positive and significant effect towards the customers' buying decision. Furthermore, the results of this study can be beneficial for both Maybelline cosmetics and the celebrity. First, the benefit for Maybelline is that the usage of celebrity endorsement can brought advantages for the brand. So with this study, the marketing division of Maybelline cosmetics could gain insights on what happens on Indonesian market. The finding of this study is that people trust more when the company used an attractive and experienced celebrity endorser. It can be conclude that the strategy of celebrity endorsement can be an effective competitive strategy in order to gain customers' attention as long as the right celebrity is found. Moreover, people now consider more on the Brand Image since it has the ability to influence the customer's buying decision (Foster, 2017). It can be conclude that company have to enhance the Brand Image in the minds' of customers in order to strengthen their buying decision (Moh, Nur, \& Rommy, 2018).

The celebrity endorser can gain insight from this study that physical attractiveness is important, but customer can trust them more when they are having a skill in endorsing, knowledge about the product. Moreover, consumers will respect the celebrity endorser more when they have a good personal quality (Ifeanyichukwu, 2016). For the next study, it is expected to be able to broaden the study, and develop this research using other variables that may have an effect towards the buying decision that is not yet listed in this study. Since the buying decision is not only influenced by promotion and brand image (Moh et al., 2018), and this study has the result of adjusted $\mathrm{R}^{2}$ of $59.9 \%$ which means $31.1 \%$ can be influenced by the other variables that is not in this study and is expected to be developed by the future studies.

\section{References}

Aaker, D. A., \& Biel, A. L. (2013). Brand Equity \& Advertising: Advertising's Role in Building Strong Brands (1st ed.).Lawrence Erlbaum Associates. https://books.google.co.id/books?id=Cb3eAQAAQBAJ\&printsec=frontcover\&source=gbs_ViewAPI\&redir_esc= $\mathrm{y} \# \mathrm{v}=$ onepage $\& q \& \mathrm{f}=$ false

Aini, I. N. (2015). Analisis Celebrity Endorser, Brand Image dan Pengaruhnya Terhadap Keputusan Pembelian Konsumen Sepeda Motor Merek Yamaha di Surakarta. Skripsi, Universitas Muhammadiyah Surakarta.

Alexandrescu, M.-B., \& Milandru, M. (2019). Promotion as a form of Communication of the Marketing Strategy. Land Forces Academy Review, 23(4), 268-274. https://doi.org/10.2478/raft-2018-0033

Brata, B. H., Husani, S., \& Ali, H. (2017). The Influence of Quality Products, Price, Promotion, and Location to Product Purchase Decision on Nitchi At PT. Jaya Swarasa Agung in Central Jakarta. Saudi Journal of Business and Management Studies, 2(4B), 433-445. https://doi.org/10.21276/sjbms

Boone Jr, H. N., \& Boone, D. A. (2012). Analyzing Likert data. Journal of Extension, $50(2), 5$.

Chhajer, D., Naidu, K., \& Shah, N. V. (2015). Study of Impact of Celebrity Endorsement on Consumer Buying Behaviour. International Conference on Technology and Business Management, 417-423.

Cho, E., \& Kim, S. (2015). Cronbach's Coefficient Alpha: Well Known but Poorly Understood. Organizational Research Methods, 18(2), 207-230. https://doi.org/10.1177/1094428114555994

Diallo, M. F., Chandon, J. L., Cliquet, G., \& Philippe, J. (2013). Factors Influencing Consumer behaviour towards store brands: Evidence from the French market. International Journal of Retail \& Distribution Management, 41(6), 422-441. https://doi.org/10.1108/09590551311330816

Foster, B. (2017). Impact of Brand Image on Purchasing Decision on Mineral Water Product "Amidis" (Case Study on Bintang Trading Company). American Research Journal of Humanities and Social Sciences, 2(1), 1-11. https://doi.org/10.21694/2378-7031.16023 
Friesner, T. (2014). Promotion. MarketingTeacher.Com. http://www.marketingteacher.com/promotion/

Gitman, L. J., McDaniel, C., Shah, A., Reece, M., Koffel, L., Talsma, B., \& Hyatt, J. C. (2018). Introduction to Business. Retrieved from https://openstax.org/details/books/introduction-business

Global Business Guide Indonesia. (2016). Overview of Indonesian Cosmetic Sector: Growing Domestic and Export Markets.

Gupta, S. (2009). How Do Consumers Judge celebrities' Irresponsible Behavior? An Attribution Theory Perspective. The Journal of Applied Business and Economics, 10(3), 1.

Halonen-Knight, E., \& Hurmerinta, L. (2010). Who endorses whom? Meanings transfer in celebrity endorsement. Journal of Product and Brand Management, 19(6), 452-460. https://doi.org/10.1108/10610421011085767

Hanzaee, K. H., \& Farsani, F. T. (2011). The Effects of Brand Image and Perceived Public Relation on Customer Loyalty. World Applied Sciences Journal, 13(2), 277-286.

Hsin Chang, H., \& Wang, H. W. (2011). The Moderating Effect of Customer Perceived Value on Online Shopping Behaviour. Online Information Review, 35(3), 333-359. https://doi.org/10.1108/14684521111151414

Ifeanyichukwu, C. D. (2016). Effect of Celebrity Endorsements on Consumers Purchase Decision in Nigeria. International Research Journal of Management, IT \& Social Sciences, 3(9), 103. https://doi.org/10.21744/irjmis.v3i9.261

Jamil, R. A., \& Hassan, S. R. ul. (2014). Influence of celebrity endorsement on consumer purchase intention for existing products: a comparative study. Journal of Management Info, 1(4), 1-23. https://doi.org/10.31580/jmi.v4i1.18

Juneja, P. (2015). Brand Image.

Kansu, A. S., \& Mamuti, A. (2013). The Use of Celebrity Endorsement as Marketing Communication Strategy by Turkish Airlines. International Journal of Academic Research in Business and Social Sciences, 3(12). https://doi.org/10.6007/ijarbss/v3-i12/484

Karlina, A. Y. (2018). Pengaruh Karakteristik Celebrity Endorser Raisa Andriana Dalam Iklan Terhadap Minat Beli Konsumen Pada Produk Luwak White Koffie. Skripsi, Universitas Sanata Dharma. https://doi.org/10.1017/CB09781107415324.004

Keller, K. L. (2008). Strategic Brand Management: Building, Measuring, and Managing Brand Equity (3rd ed.). New Jersey: Pearson Education.

Kotler, P., \& Keller, K. L. (2013). Marketing Management (14th ed.). Pearson.

Kunjana, G. (2018). Industri Kosmetik Nasional Tumbuh 20\%.

Lau, K. C., \& Phau, I. (2007). Extending Symbolic Brands Using Their Personality: Examining Antecedents and Implication Towards Brand Image Fit and Brand Dilution. Psychology \& Marketing, 24(5), 421-444. https://doi.org/10.1002/mar

Moh, N. B. H. H., Nur, A. R. Y. N., \& Rommy, A. S. N. (2018). Effect Of Brand Image And Price Perception On Purchase Decision. Journal of Business and Management, 20(8), 76-81. https://doi.org/10.9790/487X2008027681

Oladepo, O. I., \& Abimbola, O. S. (2015). The Influence of Brand Image and Promotional Mix on Consumer Buying Decision-a Study of Beverage Consumers in Lagos State, Nigeria. British Journal of Marketing Studies, 3(4), 97-109.

Oscar, Y., \& Keni, K. (2019). Pengaruh Brand Image, Persepi Harga, Dan Service Quality Terhadap Keputusan Pembelian Konsumen. Jurnal Muara IImu Ekonomi Dan Bisnis, 3(1), 20. https://doi.org/10.24912/jmieb.v3i1.3300 
Jurnal Bisnis dan Manajemen
http://jurnal.unmer.ac.id/index.php/jbm/index
Volume 8 No 1

2021

HIm. 82 - 90

Pahwa, A. (2020). What Is Brand Image? Definition, Importance \& Example. Feedough.Com. https://www.feedough.com/brand-image-explanation-examples/

Park, H. J., \& Lin, L. M. (2020). The effects of match-ups on the consumer attitudes toward internet celebrities and their live streaming contents in the context of product endorsement. Journal of Retailing and Consumer Services, 52(May 2019). https://doi.org/10.1016/j.jretconser.2019.101934

Schiffer, J. (2017). Why Maybelline is Winning at Social Media.

Schimmelpfennig, C., \& Hunt, J. B. (2020). Fifty years of celebrity endorser research: Support for a comprehensive celebrity endorsement strategy framework. Psychology and Marketing, 37(3), 488-505. https://doi.org/10.1002/mar.21315

Schlecht, C. (2003). Celebrities' Impact on Branding. Center on Global Brand Leadership. Colombia Business School: New York, 10027(212), 13.

Sengkey, C. S., \& Wenas, R. S. (2015). Analysis of Brand Image, Store Atmosphere and Psychology on Purchasing Decision At Time Out Sport Cafe IT Center Manado. Jurnal EMBA, 3(1), 1162-1172.

Shimp, T. A. (2003). Periklanan Promosi Aspek Tambahan Komunikasi Pemasaran Terpadu (5th ed.). Jakarta: Erlangga.

Silva, R. V. Da, \& Alwi, S. F. S. (2008). Online Corporate Brand Image, Satisfaction and Loyalty. Journal of Brand Management, 16(3), 119-144. https://doi.org/10.1057/palgrave.bm.2550137

Storm, M. (2020). 5 Types of Social Media and Examples of Each.

Suwitho, Nuha, S. U., \& Soekotjo, H. (2018). The Impact Of Celebrity Endorser, Trust and Product Quality to The Purchase Decision Mediated By The Word Of Mouth. Asian Academic Society International Conference (AASIC), 367-373.

Wijaya, B. S. (2013). Dimensions of Brand Image: A Conceptual Review from the Perspective of Brand Communication. European Journal of Business and Management, 5(31), 55-65. https://doi.org/10.13140/ejbm.2013.55.65

Wijayaningrum, L. A., Kusumawati, A., \& Nuralam, I. P. (2018). The Effect of Celebrity Endorser on Brand Awareness and It's Impact on Purchase Decision. Jurnal Administrasi Bisnis, 60(3), 78-86. 